\title{
Suitability of Southern Pines, Other Selected Crops, and Nutsedge to a Longidorus sp. Associated with Stunting of Loblolly Pine Seedlings
}

\author{
S. W. Fraedrich and M. M. Cram, United States Department of Agriculture (USDA) Forest Service, Athens, GA \\ 30602; and Z. A. Handoo, USDA Agricultural Research Service, Nematology Laboratory, BARC-West, Beltsville, \\ MD 20705
}

\begin{abstract}
Fraedrich, S. W., Cram, M. M., and Handoo, Z. A. 2003. Suitability of southern pines, other selected crops, and nutsedge to a Longidorus sp. associated with stunting of loblolly pine seedlings. Plant Dis. 87:1129-1132.

An undescribed needle nematode (Longidorus sp.) has been associated with severely stunted loblolly pine seedlings at a south Georgia nursery. Containers with selected crop and weed species were infested with 100 or 200 adults and juveniles of the Longidorus individuals to evaluate host suitability. Nematode populations increased in containers with slash, loblolly, and longleaf pine seedlings. The Longidorus sp. significantly reduced the dry root weights of slash $(P=0.008)$ and loblolly $(P=0.047)$ but not longleaf $(P=0.095)$ pine compared with controls. Populations of Longidorus decreased on nutsedge and small grains, including wheat, rye, oat, sorghum, and millet; and, in most experiments, populations decreased to levels found in fallow containers. Populations decreased on tomato and cabbage but increased slightly on red oak. The periodic removal of fields from pine production to grow cover crops consisting of small grains or to maintain fallow fields may be an important practice for management of this Longidorus sp.
\end{abstract}

Areas of stunted and chlorotic loblolly pine (Pinus taeda L.) seedlings have been periodically observed at the Flint River Nursery (Byromville, GA). An undescribed needle nematode (Longidorus sp.) has been associated with the problem and, in a controlled study, the nematode was found to damage root systems of loblolly pine (6). Root systems of seedlings affected by the disease are greatly reduced in size and lack lateral and feeder roots, resulting in seedlings that are severely stunted. Seedling damage usually is confined to small patches when initially observed; however, in 2001, seedlings were noticeably affected by the disease over large areas of one field, rendering much of the production unharvestable.

The Flint River Nursery was established in 1987 on agricultural fields that reportedly were used for the production of cabbage and other crops. The nursery currently produces a large variety of forest tree seedlings to support Georgia's reforestation programs. Loblolly, longleaf $(P$. palustris Mill.), and slash ( $P$. elliottii Engelm. var. elliottii) pine seedlings constitute a major portion of the yearly

Corresponding author: S. W. Fraedrich

E-mail: sfraedrich@fs.fed.us

Accepted for publication 22 April 2003.

Publication no. D-2003-0626-02R

This article is in the public domain and not copyrightable. It may be freely reprinted with customary crediting of the source. The American Phytopathological Society, 2003. production. Hardwood seedlings also are produced and include numerous species of oak (Quercus spp.). The nursery uses a variety of small grains as cover crops when fields are not in production. Certain weed species, most notably purple and yellow nutsedge (Cyperus rotundus $\mathrm{L}$. and $C$. esculentus L., respectively), can be problems in production fields if not controlled by fumigation or presowing herbicide applications. The field with the nematode problem also has been used in recent years to produce oak and other hardwood seedlings.

Management of plant-parasitic nematode populations can be achieved with the rotation of host and nonhost crops if the species of nematode has a narrow host range (13). The host range of the Longidorus sp. associated with damage to loblolly pine seedlings presently is not known. This study was undertaken to determine if slash and longleaf pines are also suitable hosts for the Longidorus sp., and if their root systems are susceptible to damage. We also evaluated the host suitability of small grains that typically are used as cover crops at the nursery, as well as oak, cabbage, tomato, and yellow and purple nutsedge.

\section{MATERIALS AND METHODS}

Pine species. Host suitability and susceptibility to damage by the Longidorus sp. was determined for slash, longleaf, and loblolly pine in two experiments. The experiments were conducted in growth chambers. In each experiment, Longidorusinfested and noninfested treatments were established for each pine species. There were four containers (replications) for each pine species and treatment combination. Containers were $7 \mathrm{~cm}$ high by $10 \mathrm{~cm}$ wide, and the soil used in containers was a loamy sand $(86 \%$ sand, $9 \%$ silt, $5 \%$ clay; $\mathrm{pH}$ 5.6, $1.8 \%$ organic matter) from the Flint River nursery. Soil was microwaved in $2,000-\mathrm{g}$ batches for $8 \mathrm{~min}$ and approximately $650 \mathrm{~g}$ was added to each container. Seeds were placed in $30 \%$ hydrogen peroxide for up to $60 \mathrm{~min}$ (1) and rinsed three times with sterile distilled water. Loblolly pine seeds then were stratified for 30 to 60 days prior to germination; slash and longleaf pine seeds were not stratified. Seeds were germinated under sterile conditions at $25^{\circ} \mathrm{C}$ on germination paper in clear containers (17.5 by 12.5 by $6 \mathrm{~cm}$ ). Five germinated seeds were transplanted to containers with microwave-treated soil. The Longidorus sp. was produced on loblolly pine seedlings grown in containers at $22^{\circ} \mathrm{C}$ for 14 to 26 weeks, and extracted from soil using the procedure of Flegg (4) with modifications by Fraedrich and Cram (6). Nematodes were hand picked, and 100 individuals in experiment 1 or 200 individuals in experiment 2 were added to each container in the Longidorus-infested treatment. Containers were placed in a growth chamber at $22^{\circ} \mathrm{C}$ with a 14 -h photoperiod for 19 weeks in experiment 1 and 26 weeks in experiment 2. At the end of the experiments, nematodes were extracted from soil as previously described and populations of the Longidorus sp. were determined for each container. Roots of seedlings were removed at the root collar and dried for 48 $\mathrm{h}$ at $80^{\circ} \mathrm{C}$, after which root dry weights were determined. The nematode reproduction factor $(\mathrm{Rf}=$ final population of all juveniles and adults divided by the initial population) was calculated as a measure of host suitability among the different plant treatments tested (11). Plant species with Rf values less than 1 were considered to be nonhosts or poor hosts for the Longidorus $\mathrm{sp}$., and those species with $\mathrm{Rf}$ values greater than 1 were considered to be hosts.

Statistical comparisons of the final Longidorus populations among pine species in infested containers were conducted by an analysis of variance (ANOVA) using PROC GLM in SAS (The SAS System for Windows, version 8.01; SAS Institute, Inc., Cary, NC), and Tukey's honest significant difference (HSD) test was used 
be nonhosts for the Longidorus sp. In experiments 1, 2, and 4, Longidorus populations decreased in containers with small grains and nutsedge to the levels found in fallow containers. In experiment 3 , where there was no fallow treatment, the Rf value for oat was only 0.01 and the final population of Longidorus in this treatment was significantly less than populations for all other plant species evaluated in this experiment. Final Longidorus populations in containers with cabbage and tomato were greater than those in containers with oat, but $\mathrm{Rf}$ values for cabbage and tomato were below 1.0, indicating that these species were also nonhosts or poor hosts. The $\mathrm{Rf}$ value of 1.12 for northern red oak indicated that this species is a host, although not as suitable as loblolly pine. The Longidorus sp. was not found in noninfested containers with loblolly pine at the end of experiments 1 and 2, but minor contamination was noted in experiments 3 and 4 . One uninfested container had 6 Longidorus nematodes in experiment 3 and, in experiment 4 , one container was contaminated with 22 nematodes and another container with 1 nematode of the Longidorus sp.

\section{DISCUSSION}

Slash, loblolly, and longleaf pines should be regarded as hosts for the Longidorus sp., and the possibility of seedling damage by this nematode exists for any of these pine species. Populations of Longidorus developed similarly on all pine species, with concomitant root damage on loblolly and slash pine seedlings in experiment 2 . The lack of discernable differences for the root dry weight of longleaf pine seedlings in infested and noninfested treatments may be related to the growth and development characteristics of this species. Longleaf pines are unique among pine species in that their seedlings remain in a stemless condition known as a 'grass stage' during the early years of their development. Seedlings develop extensive root systems during this stage (2). This unique feature may have prevented the expression of differences between treatments at the initial Longidorus populations used in these experiments.

In a previous study, 100 nematodes of the Longidorus sp. per container were sufficient to cause a reduction in the dry weight of loblolly pine root systems (6). Although a reduction in root weight for loblolly pine was observed at the rate of 200 nematodes per container in the present study, no reduction was observed at 100 nematodes per container. However, slight methodological changes in the present study may have affected results. In the previous study, less soil was used in each container and, therefore, there were more nematodes per unit volume of soil than in the present study. Furthermore, nematodes in the previous study were extracted from field soil, and most nematodes were adults or large juveniles ( $>5.0 \mathrm{~mm}$ in length). In the present study, the Longidorus sp. was reared in growth chambers, and a 50/50 ratio of adults and larger juveniles to smaller juveniles was used to infest containers.

Longidorus $\mathrm{Rf}$ values for loblolly pine ranged from 1.64 to 14.05 among the six experiments in this study. This variation likely was due to a number of factors, including subtle variation among the experiments in nematode production, elapse time between extraction of nematodes and handpicking them, and nematode storage prior to infesting containers. In the first experiment, nematodes used to infest many containers were stored in water at $6^{\circ} \mathrm{C}$ for up to $24 \mathrm{~h}$; however, in later experiments, nematodes were placed immediately into containers after they were handpicked. The Rf value of 1.64 for loblolly pine in the first experiment was the lowest among the six experiments in this study. This low $\mathrm{Rf}$ value may have been the result of nematode mortality or loss of vigor during the brief storage prior to infesting containers.

Sorghum, wheat, rye, oat, millet, and yellow and purple nutsedge appeared to be nonhosts for the Longidorus sp. In all of the experiments, the Longidorus population decreased in containers with small grains and nutsedge similarly to populations found in fallow containers, or declined to exceptionally low population levels (i.e., oat in experiment 3). Many of the Longidorus individuals that survived in containers with small grains and nutsedge were larger juveniles and adults, and generally there was no evidence of reproduction in these containers. According to Nusbaum and Barker (10), there will be no reproduction at all with nonhosts, and populations will decline at about the same rate as those under bare fallow. The use of small grains as cover crops appears to be an acceptable and desirable practice in pine seedling nurseries infested with this Longidorus sp. Additional research is necessary to better clarify the suitability of oak and tomato as hosts for this Longidorus sp. Although the Rf value was above 1.0 for oak and below 1.0 for tomato in experiment 3 , the final population of Longidorus did not differ significantly between these plant species.

The Longidorus sp. at the Flint River Nursery probably was not carried over from cultivation of cabbage because this species appears to be either a nonhost or a poor host. Presently, the origin of this nematode is not clear. We have been unable to find the Longidorus sp. in natural areas around the nursery that contain pine, oak, and bald cypress (Taxodium distichum (L.) Rich.), although we have found a morphologically identical Longidorus sp. in pine seed orchards that border the nursery (7). These seed orchards have been established since the founding of the nursery in 1987, and their importance as a source of inoculum for nursery beds is unknown. Surveys for the Longidorus sp. are continuing, and possible associations of the nematode with various herbaceous and woody plants that occur within and around the nursery are being investigated.

The nursery normally produces two pine seedling crops in fields following soil fumigation. Cover crops that consist of various small grains then are grown in fields for 2 years before refumigation. The field at the Flint River Nursery where stunted pine seedlings have occurred has not been part of this standard regime. The field has been in continuous seedling production since 1990 and was used to produce pine and hardwood seedlings. Patches of stunted loblolly pine seedlings were observed in the southernmost sections of the field in most years from 1996 through 1999, although the problem was undiagnosed. Some sections of this field were fumigated in 1998 and again in 2000; however, in each instance, the disease recurred within these sections in the second year of pine production. A complete history of the fumigation and crop production in this field has been documented (3).

According to Ruehle (13), nematode damage in forest tree nurseries typically is restricted to spots in nursery beds when first observed. This normally has been our experience with the damage caused by the needle nematode at the Flint River nursery, although the disease has appeared to spread over time with the yearly development of new infestation foci and enlargement of older foci. When seedling damage first appears, patches typically are small, often ranging in length from 3 to $9 \mathrm{~m}$ of nursery bed (6). In 2001, seedling damage was exceptional in some sections during the second year of production following fumigation (3). Affected areas were considerably larger and exceeded $90 \mathrm{~m}$ in length in some beds.

Longidorus spp. are known to occur at soil depths of at least a meter $(8,14)$, and some Longidorus spp. are most abundant at soil depths greater than $60 \mathrm{~cm}(5,12)$. Nursery fields typically are fumigated with methyl bromide injected at a depth of approximately 15 to $20 \mathrm{~cm}$. Although these relatively shallow injections can provide high concentrations of methyl bromide in the upper $30 \mathrm{~cm}$ of soil, methyl bromide concentrations decrease rapidly with soil depth, and may occur only at insignificant quantities deeper in the soil (9). Therefore, nematodes found in the deeper soil strata most likely are below the zone where standard fumigation practices used in forest tree nurseries are most effective. Although the elimination of the Longidorus sp. from the upper soil strata by fumigation permits pine seedlings to develop normal root systems early in the growing season, abundant roots are available later in the 
growing season for needle nematodes that survive fumigation. These factors could favor increased population development that could greatly impact subsequent pine crops grown in an infested field. Practices such as maintaining fallow fields or growing cover crops for one or more years following production of pine seedling crops may be important components of an integrated management program for this Longidorus sp.

\section{ACKNOWLEDGMENTS}

We thank A. Nyczepir and E. Barnard for helpful comments and suggestions on this manuscript, $\mathrm{S}$. Best for technical assistance, and personnel at the Flint River Nursery for their help and cooperation.

\section{LITERATURE CITED}

1. Barnett, J. P. 1976. Sterilizing southern pine seeds with hydrogen peroxide. Tree Plant. Notes 27:17-24.

2. Boyer, W. D. 1990. Pinus palustris Mill. Longleaf Pine. Pages 405-412 in: Silvics of North America. Volume 1, Conifers. R. M. Burns and B. H. Honkala, eds. U. S. Dep. Agric. Agric. Handb. 654. U.S. Government Printing Office, Washington, DC.
3. Cram, M. M., Fraedrich, S. W., and Fields, J. Stunting of southern pine seedlings by a needle nematode (Longidorus sp.). Pages 26-30 in: National Proceedings-Forest and Conservation Nursery Associations-2002. L. E. Riley, K. K. Dumroese, and T. D. Landis, eds. Proceedings RMRS-P-28. U.S. Dep. Agric. For. Serv. Rocky Mountain Research Station. Ogden, UT.

4. Flegg, J. J. M. 1967. Extraction of Xiphinema and Longidorus species from soil by a modification of Cobb's decanting and sieving technique. Ann. Appl. Biol. 60:429-437.

5. Flegg, J. J. M. 1968. The occurrence and depth distribution of Xiphinema and Longidorus species in south-eastern England. Nematologica 14:189-196.

6. Fraedrich, S. W., and Cram, M. M. 2002. The association of a Longidorus species with stunting and root damage of loblolly pine (Pinus taeda L.) seedlings. Plant Dis. 86:803807.

7. Fraedrich, S. W., Cram, M. M., and Handoo, Z. A. 2002. Host range and distribution of a Longidorus sp. associated with stunted loblolly pine seedlings. (Abstr.) Phytopathology 92:S26.

8. Hunt, D. J. 1993. Aphelenchida, Longidoridae and Trichodoridae: Their Systematics and Bionomics. CAB International, Wallingford, UK.
9. Munnecke, D. E., and Van Gundy, S. D. 1979 Movement of fumigants in soil, dosage responses, and differential effects. Annu. Rev. Phytopathol. 17:405-429.

10. Nusbaum, C. J., and Barker, K. R. 1971 Population dynamics. Pages 303-323 in: Plant Parasitic Nematodes. Volume I. Morphology, Anatomy, Taxonomy, and Ecology. B. M. Zuckerman, W. F. Mai, and R. A. Rohde, eds. Academic Press, New York.

11. Nyczepir, A. P., and Bertrand, P. F. 1990. Host suitability of selected small grain and field crops to Criconemella xenoplax. Plant Dis. 74:698-701.

12. Ploeg, A. T. 1998. Horizontal and vertical distribution of Longidorus africanus in a bermudagrass field in the Imperial Valley, California. J. Nematol. 30:592-598.

13. Ruehle, J. L. 1972. Nematodes of Forest Trees. Pages 313-334 in: Economic Nematology. J. M. Webster, ed. Academic Press, London.

14. Shurtleff, M. C., and Averre, C. W., III. 2000. Diagnosing Plant Diseases Caused by Nematodes. The American Phytopathological Society, St. Paul, MN

15. Steel, R. G. D., and Torrie, J. H. 1980 Principles and Procedures of Statistics: A Biometrical Approach. McGraw-Hill, New York. 